\title{
Effect of vitamin- E on cypermethrin induced toxicity in cerebral cortex of wistar albino rats: A histological study
}

\author{
Samyog Mahat, Chandra Bhushan Jha, Shamsher Shrestha, Sarun Koirala \\ Deparment of Human Anatomy, B.P. Koirala Institute of health science, Dharan, Nepal
}

\section{Corresponding Author:}

Dr Samyog Mahat; Email: samyoganatomy@gmail.com Contact: 9817388511

\begin{abstract}
Backgrounds: Cypermethrin, class II pyrethroid pesticides, is commonly used in the agricultural field and house pest controls. Cypermethrin leads to neurotoxicity by crossing the blood-brain barrier, inducing oxygen stress in brain tissue. Vitamin-E is an antioxidant, involving in protecting membrane stability against free radicals induced peroxidants. This study was conducted to see the protective effect of vitamin-E on cypermethrin induced toxicity.

Methodology: Fifty healthy Wistar albino rats of either sex weighing 150-200 grams were randomly selected \& divided into five groups. Rats in first group served as control. Rats in second and fourth group were given cypermethrin orally at $20 \mathrm{mg} / \mathrm{kg} / \mathrm{BW}$ for 14 and 28 days respectively. Rats in third and fifth group were give cypermethrin plus vitamin-E $2.5 \mathrm{ml} / \mathrm{kg} / \mathrm{BW}$ orally for 14 and 28 days respectively. Rats were sacrificed and the brain was removed. Tissue processing was done. Histological analysis was carried out and statistical analysis was performed by the use of SPSS. Result: Cypermethrin treated rats showed decreased body and brain weight with severe neuronal vacuolation and decrease glial cell. While cypermethrin plus vitamin-E treated group showed increased body and brain weight, with normal glial cell and mild neuronal changes were observed. Conclusion: Cypermethrin in combination with vitamin-E minimized its harmful effect which was evidenced by improving body and brain weight gain and histological changes.

Keywords: Cypermethrin, Vitamin-E, Cerebrum, Central Nervous System, Glial cell.
\end{abstract}

\begin{tabular}{|c|c|c|}
\hline \multicolumn{2}{|c|}{ Access this article Online } & Article Info. \\
\hline Quick Response Code & Website: & How to cite this article in Vancouver Style? \\
\hline & www.jkahs.org.np & $\begin{array}{l}\text { Mahat S, Jha CB, Shrestha S, Koirala S. Effect of } \\
\text { vitamin- E on cypermethrin induced toxicity in } \\
\text { cerebral cortex of wistar albino rats: A histological } \\
\text { study. Karnali Academy of Health Sciences } \\
\text { 2020;3(1):1-10. }\end{array}$ \\
\hline & $\begin{array}{l}\text { DOI: } \\
\text { https://doi.org/10.3126/jkahs.v3i1.28457 } \\
\text { The DOI will be functional after the } \\
\text { issue is fully published online as well } \\
\text { as in printed version. }\end{array}$ & $\begin{array}{l}\text { Received: February 10, } 2020 \\
\text { Accepted: April 6, } 2020 \\
\text { Published Online: April 8, } 2020 \\
\text { Conflict of Interest: None } \\
\text { Source of Support: None }\end{array}$ \\
\hline
\end{tabular}

\section{INTRODUCTION}


Cypermethrin is commonly used synthetic pesticide globally, ${ }^{1}$ to control agricultural and household insect pests. ${ }^{2}$ Use of cypermethrin in modern agriculture for eradication of rodents, insect ${ }^{3}$ has posed potential hazards to all living creatures. ${ }^{4}$ It is easily available in local market in the form of concentrate in suspension or mixed with other insecticide. ${ }^{5}$ Cypermethrin has be identified as important group of pesticides associated with human health risk. ${ }^{6,7}$ Cypermethrin crosses blood brain barrier, inducing free radicals generation which can lead to neurotoxicity in central nervous system. ${ }^{8-12}$ Exposure to cypermethrin may show complex syndrome including seizure, numbness, tingling sensation due to dermal exposure. ${ }^{13}$ Cypermethrin involve gene expression, ${ }^{14}$ reproductive toxicity $^{15}$ and immunotoxic effects. $^{16}$

Vitamin-E act as an antioxidant ${ }^{17,18}$ against free radicals induced. This study aims to observe the histological changes in extent to different exposed periods and to find out the protective effect of vitamin-E on toxic changes caused by cypermethrin.

\section{MATERIALS \& METHODS}

This study was conducted in laboratory of Department of Human Anatomy, B.P. Koirala institute of health science. Total duration of study was one year. Fifty healthy Wistar albino rats of either sex weighing 150-200 grams were randomly selected from the animal house of BPKIH, Dharan for the study. Sample size calculation is done using standard formula for animal study according to various article. $\mathrm{E}=\mathrm{n}-5$ (where $\mathrm{E}$; expected value that is 20 , n; number of rats, 5 ; number of groups). Taking in to account, rats can get sick or dead during experimental period, I have included extra 5 rats in each group. The rats were acclimatized for four weeks before enrolling in the study. The animals were housed in plastic cages and placed in room with 12-hour light-dark cycles. All the rats were provided free access to standard rodent diet and water ad libitum. Rats were kept in a well-ventilated room provided with the sufficient light.

The temperature of the animal house was maintained to $25 \pm 2{ }^{\circ} \mathrm{C}$. Commercially available polypropylene rat cages of size $16 " \times 11 " \times 6 "$ (inches) were used. Rat cages were fitted with "high top" wire mesh lids. Rats not more than five in number were kept in a single cage to allow rats freely move inside the cage. Rats of same sex were kept in isolated cage 20 days prior to commencement of experiment to prevent the pregnant or lactating rat being sacrificed. About $2 \mathrm{~cm}$ thick layer of paddy husk was used for flooring of the cage. The cages were regularly washed and the flooring husk was regularly changed. 
In this randomized control trial rats were randomly divided into five groups, each consisting of ten animals. The rats in the first group served as control and received no treatment. In the second group, rats were given cypermethrin daily at $20 \mathrm{mg} / \mathrm{kg} / \mathrm{BW}$ for 14 days orally. The rats in the third group were administered cypermethrin daily at 20 $\mathrm{mg} / \mathrm{kg} /$ body weight for 28 days. The rats in the fourth group were administered cypermethrin $20 \mathrm{mg} / \mathrm{kg} / \mathrm{BW}$ addition to vitamin $\mathrm{E}$, dissolved in olive oil and given at a dose level of $2.5 \mathrm{ml} / \mathrm{kg} / \mathrm{BW}$ orally by using stomach tube for 14 days. The rats in fifth group were administered cypermethrin $20 \mathrm{mg}$ / kg / BW in addition to vitamin-E $2.5 \mathrm{ml} / \mathrm{kg}$ / BW for 28 days.

On day 15 and 29 day rats from each experimental group were given ketamine 75 $\mathrm{mg} / \mathrm{kg} / \mathrm{BW}$, intramuscular and sacrificed. Brains were taken out by cranial dissection. Tissue processing was carried out after preparing the permanent slide of cerebral cortex of brain tissue and harri's hematoxylin and eosin $\mathrm{Y}$ were used as staining solution. All experimental procedures were conducted in accord with ethical guidelines and approval was taken from the Institute Review Committee (IRC), BPKIHS before conducting the study.

SPSS software was used for statistical analysis. The one way analysis of variance (ANOVA) followed by Bonferroni Post Hoc test was used. Paired t- test was used to compare the change in body weight upon the experiment. Probability values (P) less than 0.05 was considered statistically significant.

\section{RESULTS}

Five groups of rats, each group consisting of ten rats were used for 14 and 28 experimental frame. Rats from experiment group were taken out on 15th and 29th day for further procedure. In 14 days experimental group, the body weight increased significantly by $11.75 \pm 0.52$ gram in the control groups, $11.08 \pm 0.91$ gram in cypermethrin in addition to vitamin-E treated group, however the body weights increased only by $5.16 \pm 0.75$ gram in cypermethrin treated group.

ANOVA showed that there was no any difference between the mean group weights before experiment while the mean group weights after the experiment was found significant $(\mathrm{p}<.05)$.In 28 days experimental group ,the body weights increased significantly by $26.8 \pm 4.43$ gram in the control groups, $19.4 \pm 2.07$ gram in cypermethrin in addition to vitamin-E treated group. But the body weights increased only by $11.2 \pm 3.11$ gram in cypermethrin treated group. ANOVA showed that there was no any difference between the mean group weight before experiment while the mean group weight after experiment was found significant $(\mathrm{p}<.05)$. 
The data on the body weight of different summarized in the Table-1 and Table-2 groups at different time frames are

Table 1: Comparison of mean body weight of rats before and after experiment in 14 days

\begin{tabular}{|c|c|c|c|c|c|}
\hline \multirow{2}{*}{ Group(n=5) } & \multicolumn{2}{|l|}{ Body weight (gm) } & \multirow{2}{*}{$\begin{array}{l}\text { Differences in body } \\
\text { weight (gm) }\end{array}$} & \multirow{2}{*}{$\begin{array}{l}\% \\
\text { change } \\
\text { in body } \\
\text { weight }\end{array}$} & \multirow{2}{*}{ p-value* } \\
\hline & Before Experiment & After Experiment & & & \\
\hline Control (I) & $155.16 \pm 1.29$ & $166.9 \pm 1.68$ & $11.75 \pm 0.52$ & 7.57 & $<.001$ \\
\hline Сур (II) & $153.66 \pm 1.63$ & $158.8 \pm 1.47$ & $5.16 \pm 0.75$ & 3.36 & $<.001$ \\
\hline $\begin{array}{l}\text { Cyp + Vit. } \\
\text { E(IV) }\end{array}$ & $155.41 \pm 2.01$ & $165.5 \pm 2.58$ & $11.08 \pm 0.91$ & 7.13 & $<.001$ \\
\hline F value & 1.925 & 31.87 & & & \\
\hline P value** & .180 & .001 & & & \\
\hline
\end{tabular}

The symbol * indicates paired- $\mathrm{t}$ test between the mean body weight before and after the experiment and symbol ** indicates ANOVA between mean group weights before and after the experiment.

Table 2: Comparisons of mean body weight of rats before and after experiment in 28 days.

\begin{tabular}{|c|c|c|c|c|c|}
\hline \multirow{2}{*}{$\begin{array}{l}\text { Groups } \\
\quad(n=5)\end{array}$} & \multicolumn{2}{|c|}{ Body Weight (gm) } & \multirow{2}{*}{$\begin{array}{l}\text { D ifference } \\
\text { in body } \\
\text { weight (gm) }\end{array}$} & \multirow{2}{*}{$\begin{array}{l}\text { Averge } \% \\
\text { change in body } \\
\text { weight }\end{array}$} & \multirow[t]{2}{*}{$\mathrm{p}$ value* } \\
\hline & $\begin{array}{c}\text { Before } \\
\text { Experiment }\end{array}$ & $\begin{array}{c}\text { After } \\
\text { Experiment }\end{array}$ & & & \\
\hline Control (I) & $156 \pm 2$ & $182.8 \pm 3.34$ & $26.8 \pm 4.43$ & 17.17 & $<.001$ \\
\hline Сур (III) & $156.4 \pm 2.41$ & $167.6 \pm 3.04$ & $11.2 \pm 3.11$ & 7.16 & $<.001$ \\
\hline Сyp + Vit E & $153.2 \pm 2.58$ & $172.6 \pm 1.52$ & $19.4 \pm 2.07$ & 12.66 & $<.001$ \\
\hline F value & 2.76 & 39.48 & & & \\
\hline P value** & .10 & .001 & & & \\
\hline
\end{tabular}

The symbol * indicates paired- $\mathrm{t}$ test between the mean body weight before and after the experiment and symbol ** indicates ANOVA between mean group weights before and after the experiment.

In 14 days experiment group, the mean brain weights were $1.54 \pm 0.02,1.53 \pm 0.05$ and $1.55 \pm 0.01$ gram in groups one, two and four respectively. Similarly in 28 days, the mean brain weights were $1.56 \pm 0.12,1.47 \pm 0.05$ and $1.56 \pm 0.02$ gram for group one, three and five respectively. ANOVA at 14 days' time period showed no any difference between the mean group weights but showed 
significant difference in 28 days experiment time frame. The data on the brain weight of different groups at different time frames are summarized in the Table-3.

Table 3: Comparison of mean brain weights of rats

\begin{tabular}{|l|c|c|c|c|c|}
\hline \multicolumn{1}{|c|}{ Day } & $\begin{array}{c}\text { Control } \\
\text { Group (I) }\end{array}$ & $\begin{array}{c}\text { Cypermethrin } \\
\text { Group (II \& III) }\end{array}$ & $\begin{array}{c}\text { Cypermethrin + Vitamin- E } \\
\text { Group (IV \& V) }\end{array}$ & F value & P value* \\
\hline $14^{\text {th }}$ day & $1.54 \pm 0.02$ & $1.53 \pm 0.05$ & $1.55 \pm 0.01$ & 1.38 & 0.68 \\
\hline $28^{\text {th }}$ day & $1.55 \pm 0.02$ & $1.42 \pm 0.04$ & $1.58 \pm 0.01$ & 41.2 & 0.001 \\
\hline P value** & .32 & .008 & .09 & & \\
& & & & & \\
\hline
\end{tabular}

The symbol * and ** indicates ANOVA between the groups and within a group at different time frames respectively.

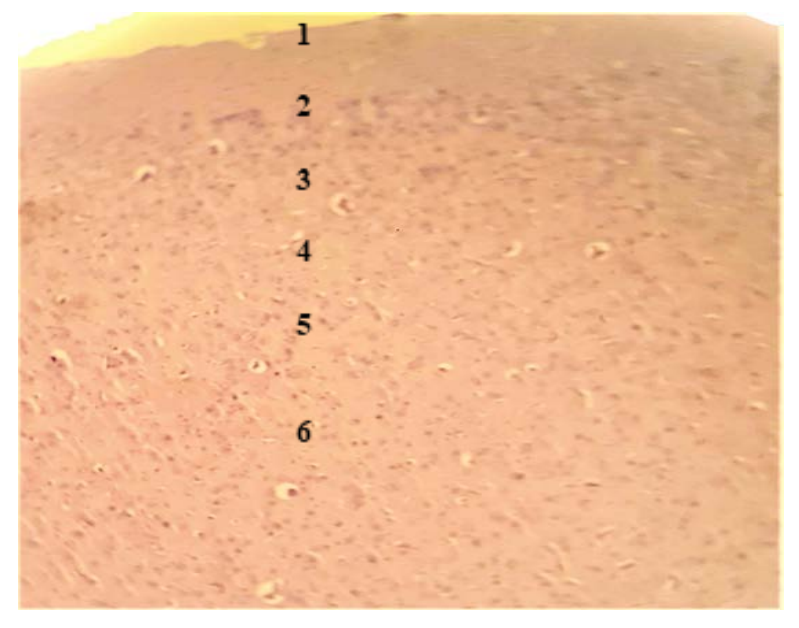

Figure 1: Photomicrograph of rat cerebral cortex section showing normal histology in 14 \& 28 days control group having normal six layers from outward namely molecular (1), external granular (2), outer pyramidal (3), internal granular (4), ganglionic (5) and multiform (6) layers. (H\&E X100)

On the basis of light microscopic preparation stained by $\mathrm{H} \& \mathrm{E}$, histological examination of cerebral cortex from control rats at 14 days and 28 days showed normal architecture having six layers from outward to inward namely molecular, external granular, pyramidal, internal granular, ganglionic and multiform layers (figure 1).

Histological examination of cerebral cortex of cypermethrin treated rats for 14 days showed almost normal architecture with six layers but disorganized, intermingled, decrease in glial cell and mild neuronal vacuolation (Figure 2).

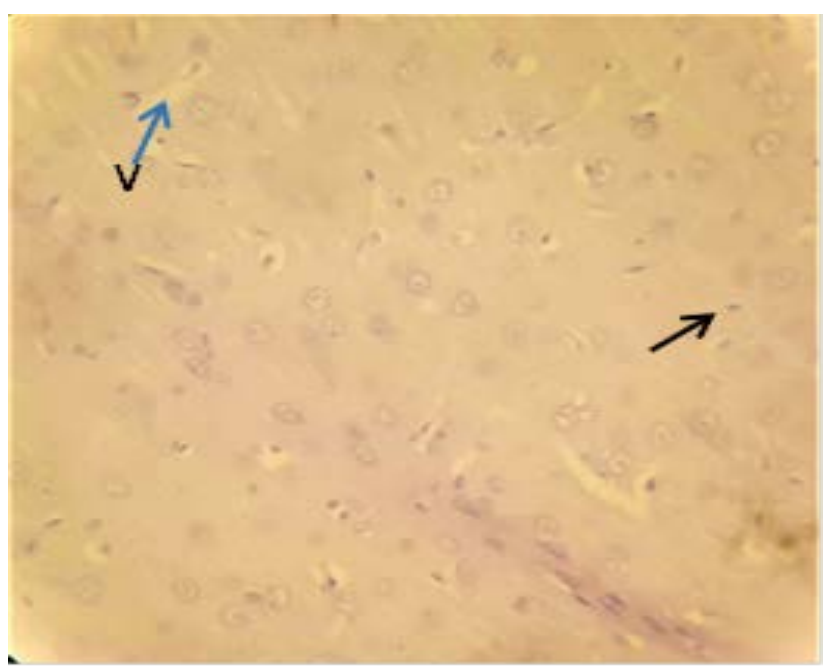


Figure 2: Photomicrograph of rat cerebral cortex section in cypermethrin treated group for 14 days showing decrease glial cell (arrow) \& mild neuronal vacuolation (V). (H\&E X400)

Cypermethrin treated rats for 28 days showed neuronal vacuolation, mild pericellular oedema, and neuronal degeneration. (Figure 3)

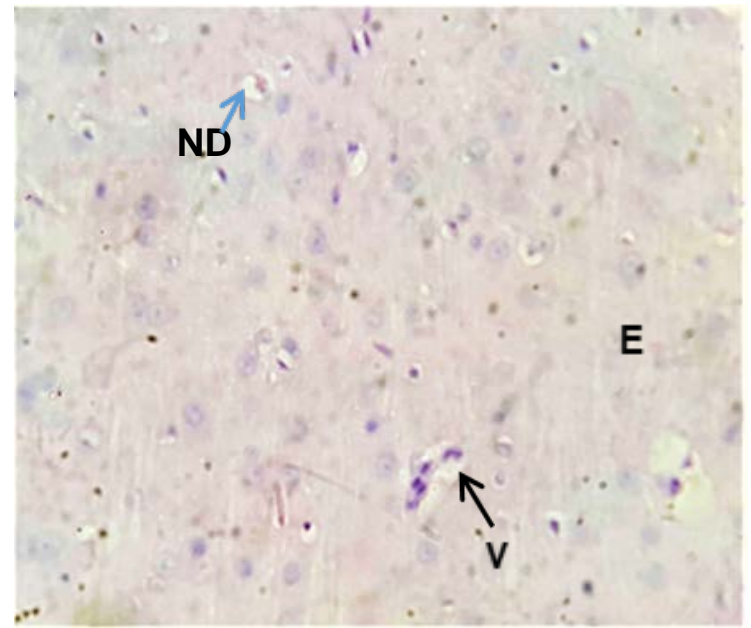

Figure 3: Photomicrograph of rat cerebral cortex section in cypermethrin treated group for 28 days showing severe neuronal vacuolation (V), mild pericellular oedema (E) and neuronal degeneration (ND). (H\&E X400)

Examination of cerebral cortex of cypermethrin in addition to vitamin-E treated rats for 14 days showed normal architecture having six layers but mild neuronal vacuolation was observed.(Figure 4)

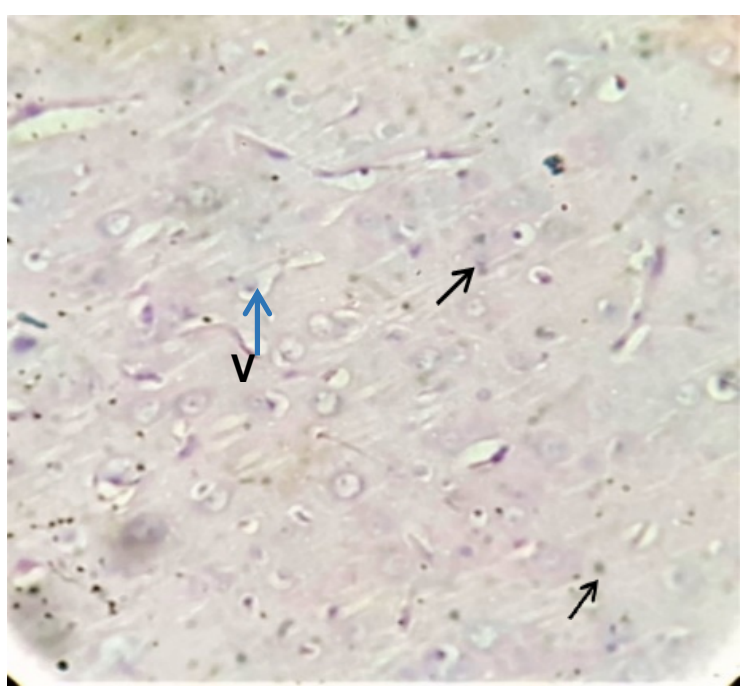

Figure4;Photomicrograph of rat cerebral cortex section in cypermethrin plus vitamin $\mathrm{E}$ treated group for 14 days showing normal glial cell (arrow) and mild neuronal vacuolation (V). (H\&E X400)

In 28 days, cypermetrin in addition to vitamin E treated rats, showed normal cerebral cortex architecture with all six layers having normal cell bodies, absence of pericelluar oedema, and no neuronal degeneration. However neuronal vacuolation still persist in this group. (Figure 5)

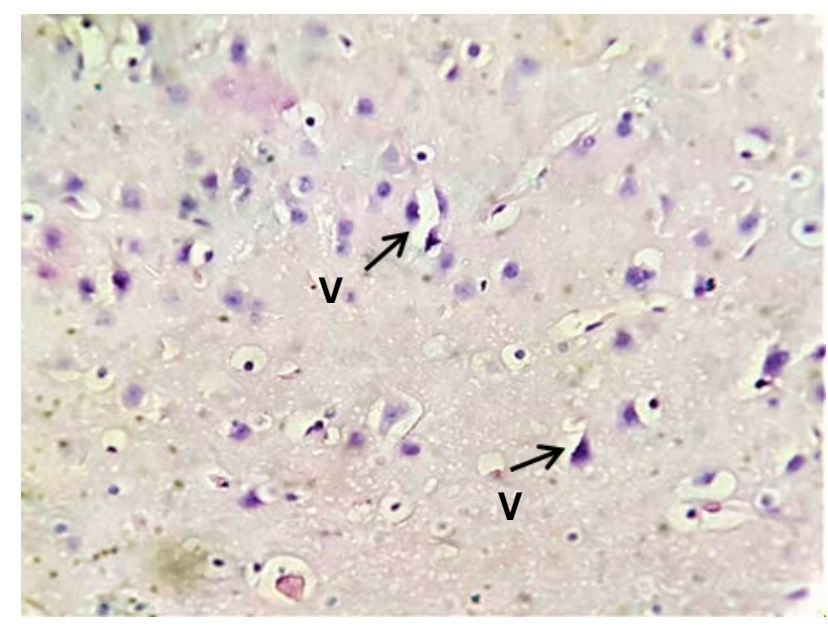

Figure 5; Photomicrograph of rat cerebral cortex section in cypermethrin plus vitamin $\mathrm{E}$ 
treated group for 28 days showing neuronal vacuolation (V). (H\&E X400)

\section{DISCUSSION}

Cypermethrin, commonly practice insecticide in modern agriculture affects the axons of central and peripheral nervous system. ${ }^{19,20}$ It can induces oxidative stress by producing excess of reactive oxygen species and reactive nitrogen species in cell or tissue resulting in oxidative damage to lipids, protein, carbohydrate and nucleic acids in brain. In this study vitamin-E was observed as neuroprotective agent.

In 14 days experimental group, the body weight of control group was increased significantly by $11.75 \pm 0.52$ gram, may be due to further developing capacity of the rats during their life span. Cypermethrin treated group has also showed increase in body weight but the change was reduced to $5.16 \pm 0.75$ gram; however the body weight gain was improved significantly by $11.08 \pm$ 0.91 gram in cypermethrin + vitamin-E treated group which resembled to control group. Similarly in 28 days experimental group, due to increase in duration, body weight shows increasing trend in the group similar to rats in 14 days experimental group. The body weights of control group had increased significantly by $26.8 \pm 4.43$ gram, while the body weights of cypermethrin treated group had increased only by $11.2 \pm 3.11$ gram; however the body weights had increased by $19.4 \pm 2.07$ gram when cypermethrin + vitamin-E was given together. The increasing rate of control and cypermethrin plus vitamin-E group very close resemblance suggesting the antioxidant property of vitamin-E in reducing the toxicity generated by cypermethrin. The loss of body mass indicates that cypermethrin induces severe toxicity and it may be due to loss of lipid, protein and other biomolecules.

The finding corroborates with study done by Hend M. Hussein (2013), the rats treated of sesame oil with cypermethrin increased significantly daily body weight and feed efficiency when compared to cypermethrin group. In another study carried out by Ehab K. Hassana (2017) showed vitamin-E with permethrin treated group showed significant increase in body weight in comparison to permethrin alone treated group.

In this study it was found that the brain weight of rats treated with cypermethrin for longer duration showed decrease in brain weight. But when vitamin-E was given along with cypermethrin with similar duration showed increase in brain weight in comparison with cypermethrin alone treated group for longer duration. The improvement in the brain weight is probably due to the antioxidant property. 
Histologically, cypermethrin treated rats for 14 days showed mild distortion of cortical architecture while the extent of severity was increased when rats treated with cypermethrin for 28 days. Different studies have revealed that at higher dose and for longer duration exposure, extensive necrosis and neuronal degeneration of cerebral cortex was evident. Similar results were reported by Odokuma E. Igho (2014) who demonstrated that 40 days administration of different concentration of cypermethrin showed distortion of the cytoarchitecture pattern with neuronal degeneration. Comparable findings were also obtained by Samar S. Elblehi who demonstrated that 60 days administration of subcutaneous cypermethrin cause marked histopathological alterations in the brain tissues which were represented by neuronal degeneration, perineuronal vacuolation, congestion of blood vessels and pericellular edema.

In our study, cypermethrin with vitamin=E treated rats for 14 days showed mild neuronal vacuolation. As the severity of damage was high in case of rats treated with cypermthrin for 28 days, the protective role of vitamin-E was seen more in the groups treated with cypermethrin in addition to vitamin-E for same duration. This findings corroborates with the results of similar study by Samar S. Elblehi ${ }^{21}$ who reported that histopathological examinations of rat's brain in cypermethrin with vitamin-E treated group showed mild lesion, which was seen as neuronal vacuolation.

\section{Limitation of this study}

We have used simple compound microscope with no camera attached so the histological picture taken was not clear as expected. Ultrathin slice of the tissue could not be obtained because of the rotatory machine available. Less number of sample size was considered.

\section{CONCLUSION}

Cypermethrin can induced neurotoxicity and histological changes in brain and is a major concern for human. Since these pesticide are widely used in agricultural field, care must be taken in handling both at home and in work place, as prolonged exposure leads to adverse health effects. Using Vitamin-E in cypermethrin exposed can minimized its toxic effect. Furthermore, restricted sale of these chemicals, user awareness, and avoidance of food contaminated with pesticide and vitamin E rich diet could be beneficial to prevent cypermethrin toxicity.

\section{Acknowledgement}

I will like to express my sincere gratitude to Dr Manisha Jha, Saru Bhattarai and 
Sunil Shreshtha for the continuous help

\section{REFERENCES}

1. Crawford MJ, Croucher A, Hutson DH. Metabolism of cis- and trans-cypermethrin in rats. Balance and tissue retention study. J Agric Food Chem. 2018;29(1):130-5.

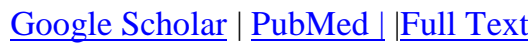

2. Suvarna SK, Layton C, Bancroft J. Bancroft's theory and practice of histological techniques. 7th ed. Suvarna S K, Layton C BJ, editor. Churchill Livingstone; 2013. 1-63. Google Scholar

3. Emmanuel Igho O, Kingsley Afoke I. A histomorphologic analysis of pyrethroid pesticide on the cerebrum and cerebellum of adult albino rats. J Exp Clin Anat. 13(2). $\underline{\text { Google Scholar }}$

4. Liao H-T, Hsieh C-J, Chiang S-Y, Lin M-H, Chen P-C, Wu K-Y. Simultaneous analysis of chlorpyrifos and cypermethrin in cord blood plasma by online solid-phase extraction coupled with liquid chromatography-heated electrospray ionization tandem mass spectrometry. J Chromatogr B.

2011;1;879(21):1961-6.

Google scholar

5. Latuszyńska J, Luty S, Raszewski G, TokarskaRodak M, Przebirowska D, Przylepa E, et al. Neurotoxic effect of dermally-applied chlorpyrifos and cypermethrin in Wistar rats. Ann Agric Environ Med. 2001;8(2):163-70. Google Scholar |PubMed |CrossRef |Full Text

6. Singh AK, Tiwari MN, Prakash O, Singh MP. A current review of cypermethrin-induced neurotoxicity and nigrostriatal dopaminergic neurodegeneration. Curr Neuropharmacol. 2012 Mar;10(1):64-71. Google Scholar

7. Khan DA, Hashmi I, Mahjabeen W, Naqvi TA. Monitoring health implications of pesticide exposure in factory workers in Pakistan. Environ Monit Assess. 2010;8;168(1-4):23140.

Google Scholar

8. Eells JT, Dubocovich ML. Pyrethroid insecticides evoke neurotransmitter release from rabbit striatal slices. J Pharmacol Exp and motivation in all the time of research.

Ther. 1988;246(2). Google Scholar

9. Narahashi T, Frey JM, Ginsburg KS, Roy ML. Sodium and GABA-activated channels as the targets of pyrethroids and cyclodienes. Toxicol Lett. 1992;64-65 Spec:429-36. Google Scholar

10. Kirby ML, Castagnoli K, Bloomquist JR. In Vivo Effects of Deltamethrin on Dopamine Neurochemistry and the Role of Augmented Neurotransmitter Release. Pestic Biochem Physiol. 1999 Nov 1;65(3):160-8.

Google scholar

11. Kale M, Rathore N, John S, Bhatnagar D. Lipid peroxidative damage on pyrethroid exposure and alterations in antioxidant status in rat erythrocytes: a possible involvement of reactive oxygen species. Toxicol Lett [Internet]. 1999 Apr 12 [cited $2018 \mathrm{Jul}$ 11];105(3):197-205. PumMed

12. Giray B, Gürbay A, Hincal F. Cypermethrininduced oxidative stress in rat brain and liver is prevented by vitamin E or allopurinol. Toxicol Lett [Internet]. 2001 Jan 3 [cited 2018 Jul 11];118(3):139-46. PubMed

13. Raj J, Mohineesh, Ray R, Dogra TD, Raina A. Acute oral toxicity and histopathological study of combination of endosulfan and cypermethrin in wistar rats. Vol. 20, Toxicology international. 2013. p. 61-7.

Google scholar

14. Bradley J, Finkbeiner S. An evaluation of specificity in activity-dependent gene expression in neurons. Prog Neurobiol. 2002 Aug;67(6):469-77. Pubmed

15. Guo J, Xu J, Zhang J, An L. Alteration of mice cerebral cortex development after prenatal exposure to cypermethrin and deltamethrin. Toxicol Lett. 2018;287:1-9. Google Scholar | Full Text | CrossRef

16. Sood R. Medical laboratory technology : methods and interpretations. 1st ed. New Delhi: Jaypee Brothers Medical Publishers; 2009. 657. Google Sxholar $\mid \underline{\text { Full Text }}$

17. Yoshida Y, Niki E, Noguchi N. Comparative study on the action of tocopherols and 
tocotrienols as antioxidant: chemical and physical effects. Chem Phys Lipids. 2003 Mar;123(1):63-75. Pubmed

18. Erin AN, Spirin MM, Tabidze L V, Kagan VE. Formation of alpha-tocopherol complexes with fatty acids. A hypothetical mechanism of stabilization of biomembranes by vitamin E. Biochim Biophys Acta [Internet]. 1984 Jul 11 [cited 2018 Jul 12];774(1):96-102. PubMed

19. Hussien HM, Abdou HM, Yousef MI.

Cypermethrin induced damage in genomic DNA and histopathological changes in brain and haematotoxicity in rats: The protective effect of sesame oil. Brain Res Bull. 2013;92:76-83. Full Text

20. Sayim F, Yavasoglu NÜK, Uyanikgil Y, Aktug H, Yavasoglu A, Turgut M. Neurotoxic Effects of Cypermethrin in Wistar Rats: a Haematological, Biochemical and Histopathological Study. J Heal Sci. 2005;51(3):300-7. Google scholar

21. Samar E, Samah O, Hossam T, Elsayed E. Protective Effect of Vitamin E and Selenium Combination on Cypermethrin-Induced Toxicity in Male Rats. Alexandria J Vet Sci. 2015;47(1):158. Google scholar 